UDC 378.14:796

\title{
Formation of professional reflection of future specialists in physical therapy, ergotherapy
}

\author{
Kopochynska Yu. ${ }^{*}$ \\ Academician Yuriy Bugay International Scientific and Technical University, Kyiv, Ukraine
}

Received: $05.03 .2020 \quad$ Accepted: 23.03 .2020

\begin{abstract}
The purpose of the study is to develop a model for the formation of professional reflection of future specialists in physical therapy, ergotherapy and to study the impact of its implementation in the process of professional training. Based on the theoretical analysis of the scientific literature, we have developed a model for the formation of professional reflection of future specialists in physical therapy and ergotherapy. The model developed is based on a reflexive approach, which assumes that a person has the capacity to take an active research position in relation to his activity and to himself as his subject, in order to critically analyze, understand and evaluate its effectiveness for its development. The approach to reflective activity allows us to consider reflection as a mechanism for the development and implementation of activity, in turn, activity is the object of reflection. The essence of this approach is most consistent with the understanding of the professional reflection of specialists in physical therapy, ergotherapy as an integral part of professional activity, which led to the development of a program of work with students on its basis. Psychological methods, a specially designed questionnaire and an expert evaluation method were used to evaluate the effectiveness of the model. Formation of professional reflection of future specialists in physical therapy, ergotherapy is presented in the form of three successive interrelated stages. The components of professional reflection of specialists in physical therapy and ergotherapy are covered. We used the methods of diagnostics of reflexivity and examination twice, before the beginning of the experimental work and after its completion. The analysis of the experimental work showed that the students of the experimental group significantly increased the level of formation of each of the components of professional reflection of specialists in physical therapy and ergotherapy. The results of the study make it possible to outline a number of unresolved problems, the development of which is dictated by the needs of the theory and practice of the entire education system. According to the results of the study, the introduction of the developed model in the process of professional training of future specialists in physical therapy and ergotherapy will contribute to the formation of professional reflection.
\end{abstract}

Key words: professional reflection, physical therapy, ergotherapy, professional training, reflection of the physical therapist.

\section{Формування професійної рефлексії майбутніх фахівців з фізичної терапії, ерготерапії \\ Копочинська Ю. В.}

Міжнародний науково-технічний університет імені академіка Ю.Бугая, Київ, Україна

\begin{abstract}
Анотація. Метою дослідження є розробка моделі формування професійної рефрлексії майбутніх фахівців 3 фізичної терапії, ерготерапії та вивчити вплив її впровадження у процес професійної підготовки. На основі теоретичного аналізу наукової літератури ми розробили модель формування професійної рефлексії майбутніх фахівців з фізичної терапії та ерготерапії. Розроблена модель базується на рефрлексивному підході, який передбачає, що людина має здатність займати активну дослідницьку позицію стосовно своєї діяльності та до себе, як до свого предмета, з метою критичного аналізу, розуміння та оцінки його ефективності для його розвитку. Підхід до рефрлексивної діяльності дозволяє розглядати рефлексію як механізм розвитку та здійснення діяльності, у свою чергу діяльність $є$ предметом рефллексії. Суть цього підходу найбільше узгоджується з розумінням профресійної рефлексії фрахівців з фізичної терапії, ерготерапії як невід'ємної
\end{abstract}

\footnotetext{
Corresponding Author: Kopochynska Yuliia Volodymyrivna, Тел. +380970928497 . E-mail: yoiliaco@ukr.net Academician Yuriy Bugay International Scientific and Technical University Ukraine, Kiev, Lane Magnitogorsk 3 (metro Chernigovskaya)

Відповідальний автор: Копочинська Юлія Володимирівна, Тел. +380970928497 .E-mail: yoiliaco@ukr.net кМіжнародний науково-технічний університет імені академіка Ю.Бугая, м.Київ, пров. Магнітогорський 3
} 
частини професійної діяльності, що зумовило розробку на їі основі програми роботи зі студентами. Для оцінки ефективності моделі були застосовані психологічні методи, спеціально розроблена анкета та метод експертного оцінювання. Формування профресійної рефрлексії майбутніх фахівців з фізичної терапії, ерготерапії представлено у вигляді трьох послідовних взаємопов'язаних етапів. Висвітлено компоненти професійної рефрлексії фахівців з фізичної терапії та ерготерапії. Методи діагностики рефрлексивності та експертиза нами проводилися двічі, до початку експериментальної роботи та після її завершення. Аналіз експериментальної роботи показав, що студенти експериментальної групи значно підвищили рівень сформованості кожного із компонентів профресійної рефрлексії фахівців з фізичної терапії та ерготерапії. Результати дослідження дозволяють окреслити коло невирішених проблем, розробка яких продиктована потребами теорії та практики всієї системи освіти. За результатами дослідження встановлено, що впровадження розробленої моделі у процес профресійної підготовки майбутніх фрахівців з фізичної терапії та ерготерапії сприятиме формуванню просресійної ресрлексії..

Ключові слова: професійна рефрлексія, фізична терапія, ерготерапія, професійна підготовка, рефрлексія фізичного терапевта.

\title{
Формирование профессиональной рефлексии будущих специалистов по физиотерапии, эрготерапии
}

\author{
Копочинская Ю. В.
}

Международный научно-технический университет имени академика Ю.Бугая, Киев, Украина

\begin{abstract}
Аннотация. Целью исследования является разработка модели формирования профрессиональной рефрлексии будущих специалистов по физической терапии, эрготерапии и изучить влияние ее внедрение в процесс профессиональной подготовки. На основе теоретического анализа научной литературы мы разработали модель формирования профессиональной рефлексии будущих специалистов по физической терапии и эрготерапии. Разработанная модель базируется на рефлексивном подходе, который предполагает, что человек обладает способностью занимать активную исследовательскую позицию по отношению к своей деятельности и к себе, как к своему предмету, с целью критического анализа, понимания и оценки его эффрективности для его развития. Подход к рефлексивной деятельности позволяет рассматривать рефлексию как механизм развития и осуществления деятельности, в свою очередь деятельность является предметом рефрлексии. Суть этого подхода больше согласуется с пониманием профрессиональной рефрлексии специалистов по физической терапии, эрготерапии как неотьемлемой части профессиональной деятельности, что обусловило разработку на ее основе программы работы со студентами. Для оценки эффективности модели были применены психологические методы, специально разработанная анкета и метод экспертной оценки. Формирование профессиональной рефлексии будущих специалистов по физической терапии, эрготерапии представлено в виде трех последовательных взаимосвязанных этапов. Освещены компоненты профессиональной рефрлексии специалистов по физической терапии и эрготерапии. Методы диагностики рефрлексивности и экспертиза нами проводились дважды, в начале экспериментальной работы и после еe завершения. Анализ экспериментальной работы показал, что студенты экспериментальной группы значительно повысили уровень сформированности каждого из компонентов профессиональной рефрлексии специалистов по физической терапии и эрготерапии. Результаты исследования позволяют очертить круг нерешенных проблем, разработка которых продиктована потребностями теории и практики всей системы образования. По результатам исследования установлено, что внедрение разработанной модели в процесс профессиональной подготовки будущих специалистов по физической терапии и эрготерапии способствовать формированию профессиональной рефлексии..

Ключевые слова: профессиональная ресрлексия, физическая терапия, эрготерапия, профессиональная подготовка, рефрлексия физизического терапевта.
\end{abstract}

\section{Introduction}

Today, the higher education system of specialists in physical therapy and ergotherapy faces the task of teaching students independent practice in the field of physical therapy and ergotherapy, taking decisive action in professional situations, that is, stimulating professional thinking, activating creative potential, and creating a steady interest in future education profession.

As one of the ways to solve the set tasks, we propose a study of the features of the formation of professional reflection of future specialists in physical therapy, ergotherapy. 
Today, the question of the development of professional reflection of future specialists in physical therapy and ergotherapy is relevant, since the professional development of these specialists is impossible without reflection, which is one of the mechanisms of this process $[6,18,25]$.

Reflection is considered as a process of awareness by a future specialist of their own feelings, thoughts and actions. The focus on professional and personal self-determination, self-realization as the most important components of the student's self-development should take a leading place in the work of the teaching staff of a professional educational institution $[12,14]$.

Reflection in the process of professional activity can manifest itself as the subject's ability to distinguish, analyze and correlate his own actions with the subject situation, to carry out arbitrary regulation of intellectual activity [34].

In the system of modern professional education, the formation of reflection is a prerequisite for the training of future specialists in physical therapy, ergotherapy for professional activities [8]. Reflection is an integral part of Gnostic, communicative, organizational, projective skills; It is an integral component in solving strategic, tactical and operational tasks; contributes to an adequate change of social roles depending on the situation of social interaction; involves finding the most effective ways out of normative and non-normative professional crises; helps to overcome the negative impact of stereotyping and projection in the activities of a physical therapist, ergotherapist [16, 21].

By professional reflection of physical therapists and ergotherapists, we mean the process of selfrecognition by a specialist of the essential characteristics of labor, aimed at analyzing, evaluating and necessary adjusting one's own professional activity, for a positive perception of it by other people [10,26]. We offer the development of professional reflection of physical therapists, ergotherapists to be associated with the formation of professionalism and the development of professional abilities of a person.

At the same time, reflection is seen as one of the main mechanisms for realizing a person's activity, a means of self-development, and the purposeful reflective interaction of a teacher and a future specialist is considered the basis for successful management of the training process [1].

Particularly relevant is the development of professional reflection of physical therapists, ergotherapists today for the training system of future specialists in physical therapy, ergotherapy [5]. This is due to the fact that student age is the most important period for mastering the means of reflective analysis and management of mental activity $[2,4,17,23]$. At the stage of mastering the profession, it is the reflexive consciousness of students that must control the process of building the image of future professional activity, help critically interpret its features [29]. Due to the fact that the professional activity of physical therapy, ergotherapy is not always clearly recognized and often realized spontaneously, the future specialist does not fully understand the specifics of his difficulties and their consequences for himself, he does not fully recognize himself, perceiving this difficulty and acting towards overcoming it [20].

If there is a sufficient amount of work on the formation of professional reflection in most cases, researchers are more likely to catalog individual techniques or conditions without building them on a single methodological basis and without creating a conceptual system for solving this problem. Recognizing the importance of the theoretical and empirical work done, we venture to suggest that the accumulated baggage of research allows us to proceed from a simple list of techniques and conditions to an attempt to build a program for the formation of professional reflection of future specialists in physical therapy and ergotherapy on a single methodological basis. The presence of a theoretical base would allow us to go from designing particular methods and conditions to designing systematic activities for the formation of professional reflection among future specialists in physical therapy and ergotherapy.

A similar experience in world science is presented by $\mathrm{H}$. Wald [30]. She proposed a model of the reflective activity of a physical therapist, developed a technology for the gradual development of professional reflection of future specialists in physical therapy, ergotherapy, based on the idea of a reflective environment, described methods and techniques for the formation of professional reflection. However, this technology mainly includes traditional forms of organization of study at a university.

We made an attempt to develop a model for the formation of professional reflection that would integrate both traditional and innovative forms of work with future specialists in physical therapy and ergotherapy. 
The purpose of the study is to develop a model for the formation of professional reflection of future specialists in physical therapy, ergotherapy and to study the effect of its implementation in the process of training specialists in physical therapy and ergotherapy using the method of experimental work.

\section{Materials and Methods}

When developing a model for the formation of professional reflection of future specialists in physical therapy and ergotherapy, we focused on the standards and requirements that are presented in the regulatory legal acts of the Ministry of Health and the Ministry of Education and Science of Ukraine [9, 27].

Based on the theoretical analysis of the scientific literature, we have developed a model for the formation of professional reflection of future specialists in physical therapy and ergotherapy. We based the model on a reflective activity approach, which assumes that a person has the ability to take an active research position in relation to his activities and to himself, as his subject, with the aim of critical analysis, understanding and evaluating its effectiveness for its development. The reflective activity approach allows us to consider reflection as a mechanism for the development and implementation of activities, in turn, activity is the subject of reflection. The essence of this approach is most consistent with the understanding of professional reflection of specialists in physical therapy, ergotherapy as an integral part of professional activity, which led us to develop a program of work with students based on it.

When designing the experimental work, we proceeded from the assumption that the model for the formation of professional reflection of future specialists in physical therapy, ergotherapy based on a reflective activity approach includes the following components:

- building a reflective educational environment;

- consistency of educational activities with the actual practice of physical therapy, ergotherapy;

- use of collective forms of activity;

- removal of psychological barriers in students during self-analysis of their professional activities;

- development of reflective evaluative abilities and skills;

- The inclusion of students in research in the field of health.

A feature of the proposed model is that the formation of professional reflection of future specialists in physical therapy, ergotherapy occurs during the study of the main disciplines of the training cycle. At the same time, various methodological forms were aimed at updating the motivational target, creative procedural, emotional volitional, communicative technological and control evaluative components of the reflection of the professional activities of specialists in physical therapy and ergotherapy.

For practical testing of our nama model, second, third and fourth year students were selected as an experimental group. The experimental base of the study was Academician Yuriy Bugay International Scientific and Technical University. The control group included 41 second-year students, 29 third-year students and 24 fourth-year students; the experimental group included 36 second-year students, 31 third-year students and 26 fourth-year students. We formed a control and experimental group of students from real study groups, while the level of student performance in both the control and experimental groups was approximately the same. In total, 187 2nd, 3rd and 4th year students took part in the study. Testing was carried out for two years, and, at the beginning of each academic year, new control and experimental groups were completed.

In the experimental group, classes in the disciplines of the vocational training were carried out on the basis of a reflective activity approach, and a model for the formation of professional reflection of future specialists in physical therapy and ergotherapy was tested. Students of the control group studied in the same disciplines, but attended electives implemented through traditional educational technologies (lectures and seminars).

To assess the effectiveness of our proposed model for the formation of professional reflection of future specialists in physical therapy, ergotherapy, we developed a diagnostic kit. We used both standardized psychological techniques and projective diagnostic techniques. As standardized methods, we used A. Karpov's reflexivity diagnostic technique (where reflection is understood as a mental property) and $V$. Ponomareva's method of determining reflexivity level [19]. 
To assess the needs of students in professional self-improvement, analysis of diverse professional tasks, independence in the choice of technologies for constructing strategies of their own interventions, as a specialist in physical therapy, ergotherapy, we have developed special profiles.

To track the dynamics of professionally significant qualities, we used the expert assessment method. The experts were teachers of disciplines of the vocational training cycle, regularly interacting with students.

Reflexivity diagnostic techniques and expert assessment were carried out by us twice, before the start of the experimental work and after its completion. When analyzing the obtained data, we focused on three levels of professional reflection of future specialists in physical therapy and ergotherapy: highest, advanced and basic.

An indicator of the highest level is the high development of all components of professional reflection. All reflective processes are organized to the maximum extent, the ability to quickly and flexibly respond to changing conditions, to change their behavior is revealed.

An advanced level is associated with the certainty and organization of the reflective activities of future specialists and is characterized by a steady need for professional and personal self-improvement, steady independence and creative activity, but still insufficient knowledge of professional technology, difficulties in solving practical problems in the field of physical therapy, ergotherapy.

The indicators of the basic level are as follows: weak severity of professional reflection, undifferentiated orientation of self-awareness of self-analysis and self-esteem in the process of activity, underdevelopment of analytical skills, low formation of professional actions, insufficient motivation and independence, lack of need for professional self-education.

\section{Results}

The model we developed for the formation of professional reflection of future specialists in physical therapy, ergotherapy based on a reflective activity approach includes the following components:

- building a reflective educational environment, involving students in non-standard situations of professional activity in the fields of physical therapy, ergotherapy, requiring a creative approach to solving situations;

- consistency of educational activities with the actual practice of physical therapy, ergotherapy;

- the use of collective forms of activity in which, thanks to group interaction, individual methods of work are corrected and professional standards and patterns are assimilated;

- removal of psychological barriers in students during self-analysis of their professional activities;

- development of reflective evaluative abilities and skills, adequate personal and professional selfesteem, self-control and self-regulation of students' own actions and mental states;

- the inclusion of students in research in the field of health.

Our model for the formation of professional reflection of future specialists in physical therapy, ergotherapy based on a reflective activity approach, taking into account the above components, suggests, on the one hand, a change in the approach to modeling training sessions in the main subjects of the training cycle.

In the model we developed, we propose to distinguish the following components of professional reflection of specialists in physical therapy and ergotherapy: motivational target, creative procedural, emotional strong-willed, communicative technological, control evaluative.

The motivational target component expresses the need for professional reflection, the need for awareness of the motives and goals of its use in the work of a physical therapist, ergotherapist.

The creative procedural component includes knowledge specifying the theoretical foundations of professional reflection of specialists in physical therapy, ergotherapy, as well as professional skills of a physical therapist, ergotherapist, allowing for reflective professional activities.

The emotional volitional component reflects the emotional value attitude to the process of forming professional reflection, the focus on the development of personal and subject-activity qualities that contribute to the effective implementation of reflective activity.

The communicative technological component expresses the pedagogical conditions for the formation of communication skills in the structure of the formation of professional reflection. 
The control evaluation component involves the assessment and self-assessment of the reflexive activity of a physical therapist, ergotherapist.

We offer the following process for simulating training sessions.

At the first stage, conducting classes is aimed at creating a theoretical knowledge base on a specific topic. The selection of knowledge occurs through the study of recommended literature and materials presented in the lecture course. The selection of material can be carried out either in the form of a free search or, if it is algorithmized by a teacher, in the form of compiling a glossary on a topic, constructing a framework of supporting concepts. At this stage, there is a development of the motivational target component of methodological reflection, since the selection of knowledge is purposeful, taking into account their further use in educational activities.

The second stage is the assimilation of the selected knowledge at the level of reproduction. Reproduction takes place in the form of a group discussion, tournament, quiz, educational game. These forms of reproduction of knowledge contribute to the development of the students reflective position, developing such components as reflective information perception, reflective analysis, reflective assessment of the obtained data, the ability to conduct scientific discussion, the ability to take into account the opinions of others, the ability to adequately perceive the comments of colleagues (procedural, meaningful, emotional will, control evaluation blocks). Such methods prepare students for the further independent search for solutions to educational research problems, and provide an idea that there is a variety of approaches to assessing, interpreting, and applying the same data.

At the third stage, there is a transfer and independent use of acquired knowledge in solving educational methodological and research problems. At this stage, the formation of common methodological, research and special methodological reflective skills. Students solve methodological and research problems and problems first using an algorithm, then independently. When solving educational problems, the skills of the processual substantive unit of methodological reflection are formed: the skills of conceptual theoretical analysis, the skills of conceptual theoretical design and modeling, the skills of scientific forecasting, the ability to adequately use methodological and diagnostic tools in research activities, the ability to put forward hypothetical assumptions, the ability to analyze the course and stages of scientific, research work, ability to adjust the course investigated $\mathrm{i}$.

For this stage, an optimal way of activity is to work in small groups. Such work allows you to effectively develop the above reflective skills in solving professional methodological and research problems, since collective cognitive activity involves generating ideas, formulating hypotheses, analyzing the work of partners in the group (and your own), planning future actions, discussing and making decisions.

At the fourth stage, students carry out a completely independent creative search. Situations are simulated when it is necessary to apply knowledge at one's discretion, when creative freedom is provided. In this case, students, on the one hand, have the opportunity to plan, design, and adjust research activities themselves, and, on the other hand, all their research activities are determined by the end result.

At this stage, the following methodological reflexive skills are finally fixed: scientific analysis, modeling, designing, forecasting, scientific retrospection; meta-cognitive skills are being formed: the skill of determining the methodological parameters of research, the skill of planning and rescheduling the course of scientific research, the skill of controlling the actions taken and the search results (procedural content block).

Thus, there is a simulation of the future professional activities of a physical therapist, ergotherapist. At the same time, the student's emotional value attitude to the upcoming professional work (emotional volitional block) is finally formed, his personal orientation is determined and professional actions are selected in relation to future professional activity in accordance with his own needs, motives and subjective control mechanism (motivational target block).

The fifth stage of each lesson is a reflective assessment level, which corresponds to the assessment unit of methodological reflection. At this stage of the class, students take assessment and self-assessment actions.

We developed a seminar training program in the form of a reflexive workshop. The program of the workshop we developed contains a number of specially selected exercises that allow the future specialist in physical therapy, ergotherapy, first of all, to change the attitude towards oneself, to increase the degree of expression of such professional personality traits and skills as empathy, the ability to understand and feel the 
condition and emotions of another person, the ability to be aware of one's own creative abilities, to design one's own professional activity.

It is important that in the classes that were conducted according to the model we developed, the real conditions of the professional activity of physical therapists were modeled and the personal experience of students was formed, allowing them not only to realize their own individual characteristics, but also to develop a sustainable motivation for self-development and self-improvement of the personality. Our use of organizational activity games ensured the actualization of professional reflection of future specialists in physical therapy, ergotherapy and the meaningful filling of the reflective plan of consciousness.

We suggested that the formation of professional reflection of future specialists in physical therapy and ergotherapy can be represented in the form of successive interconnected stages.

The first stage (cognitive propaedeutic). The goal is the formation of creative search technology, the clarification of the student's personal reflective position, the formation of the motivational and creative components of professional reflection.

The second stage (system design). The goal is the transformation of the student's personal position into the professional position of a specialist in physical therapy, ergotherapy.

In the second year, theoretical and practical courses of a professional orientation are taught, students under the guidance of university methodologists and teachers go on production practice. At this stage, the communicative and evaluative components of professional reflection of future specialists in physical therapy and ergotherapy are beginning to take shape.

The third stage (integrative generalizing). The goal is to develop the ability to organize in an environment of professional activity. At this stage (third year), an in-depth study of theoretical and practical courses continues, the process of forming technological and evaluative reflective components in the course of industrial practice is carried out, creativity and self-awareness as a creative person, a specialist in physical therapy, ergotherapy are developing.

The results of the experimental work are presented in table 1.

Table 1. The level of formation of professional reflection of future specialists in physical therapy, ergotherapy, \%

The initial stage of experimental work

\begin{tabular}{|l|l|l|l|l|l|}
\hline \multicolumn{3}{|c|}{ Control group } & \multicolumn{3}{c|}{ Experimental group } \\
\hline Highest & Advanced & Basic & Highest & Advanced & Basic \\
\hline 0 & 31 & 69 & 0 & 28 & 72 \\
\hline
\end{tabular}

The final stage of the experimental work

\begin{tabular}{|l|l|l|l|l|l|}
\hline \multicolumn{3}{|c|}{ Control group } & \multicolumn{3}{c|}{ Experimental group } \\
\hline Highest & Advanced & Basic & Highest & Advanced & Basic \\
\hline 27 & 49 & 24 & 54 & 31 & 15 \\
\hline
\end{tabular}

The data of the first diagnostic measurement showed that both the control and experimental groups are dominated by a low and medium level of professional reflection of physical therapists, ergotherapists. However, statistically significant differences between the two groups were not found.

The data obtained at the end of the experimental work show that the indicators of professional reflection of future specialists in physical therapy, ergotherapy have fundamentally changed. In both the control and experimental groups, the proportion of students with a low level of professional reflection is significantly reduced, however, in the experimental group, the increment is statistically more significant - the shift in this indicator is greater, in addition, a significantly larger number of students reaches a high level of professional reflection of specialists in physical therapy, ergotherapy. 
The results of the analysis of the results of the questionnaire suggest that the students of the experimental group showed a steady need for professional self-improvement, analysis of diverse professional tasks, independence in the choice of technologies for constructing strategies for their own interventions, as a specialist in physical therapy, ergotherapy.

These parameters in the control group are practically not expressed. In addition, expert assessments show that communication skills have increased in the experimental group.

It seems important to note that the students of the experimental group formed a more adequate selfesteem of personal and professional qualities. During the experiment, there was a decrease in overvalued self-esteem in both groups. The percentage of students with low self-esteem was significantly higher in the control group than in the experimental group. Adequate self-esteem was observed in a larger number of students of the experimental group.

\section{Discussion}

The issues of professional identity of a health professional are presented in scientific research $[3,11$, $13,15]$. However, in the study of professional abilities, reflexive processes associated with the characteristics of professional activity and work experience, as well as factors, conditions and ways of forming professional reflection of physical therapists and ergotherapists, are overlooked.

Studies in psychology and pedagogy have repeatedly made attempts to describe and test methods and techniques that contribute to the formation of professional reflection in students. So, M. Weurlander, A. Lönn, A. Seeberger, H. Hult, R. Thornberg, A. Wernerson believe that to solve this problem it is necessary to use the fulfillment of tasks simulating professional activity, organize group reflection of students' own professional activity, and also organize trainings aimed at developing social perception, interpersonal communication skills, and verbal communication [31]. Among the methods that promote the development of professional reflection, M. Nothnagle, S. Reis, R. Goldman, G. Anandarajah, R. Takashima and K. Saeki distinguish problem solving with contentious conflict content, group discussion, organizational, activity and educational games [24, 28].

A special place among the methods of forming professional reflection of future specialists in physical therapy, ergotherapy is occupied by a reflexive workshop. In previous studies, we noted its special role in the formation of a reflective environment and, analyzing the potential of a reflective workshop in additional education, we consider it as the basis of value and semantic assessments of the content and role of the activities of physical therapy and ergotherapy specialists [7].

A number of researchers list the conditions for the development of professional reflection. Thus, $A$. Madill and P. Sullivan include the organization of reflective study of professional disciplines, the formation of students' orientation toward creative self-realization, and the use of reflexive technologies in the learning process. Researchers also emphasize the importance of the experience of reflexive activity that students acquire in the process of organizing various types of professional practice [22]. Studies by S. Yardley, M. Westerman, M. Bartlett, J. Walton, J. Smith, E. Peile [33] indicate other conditions: strengthening the personality-developing functions of psychological and pedagogical disciplines and creating a reflective environment.

An original interpretation of the conditions for the formation of professional reflection of reflection is offered by A. Wong and K. Trollope-Kumar. At the stage of reflection, the understanding of experience occurs in the context of actual activity, a long-term plan of professional development and professional activity.

Obviously, the development of physiotherapy, ergotherapy reflection in students is directly related to the development of reflective qualities - introspection and self-esteem. The problem of introspection and selfesteem in philosophy, psychology and pedagogy, as a rule, is associated with the task of self-knowledge, creative development and self-improvement.

An analysis of the literature on this problem has allowed us to highlight some important theoretical points.

1. Self-analysis as a person's ability to develop and change his attitude to himself (self-esteem), to rethink and change his experience, the ability to look at himself as if from the outside, with different eyes is an important component of a professional person, development in general, and vocational education in particular. In our understanding, introspection is a necessary condition and a means of professional determination of the student's personality. 
2. Introspection allows you to be critical of yourself, constantly correlate your capabilities and requirements with the requirements of the nature of your professional activity and a specific situation, develop the ability to set real goals, change behavior and your own ideas. "I".

3. The essence of introspection is based on the development of a person's ability to reflective thinking, in the process of which there is a constant awareness of the formed personal qualities and real current activities, and on this basis their improvement and reduction to one form or another [32].

The results of the experimental work made it possible to assert that in the learning process, the ability to rethink stereotypes, the ability to understand oneself and other people, their relationships, the ability to predict the results of physical therapy programs, ergotherapy remain insufficiently developed. Students find it difficult to explain the reasons for failures in the professional activities of physical therapists, ergotherapists.

\section{Conclusion}

The theoretical analysis of the scientific methodological literature allowed us to develop a model for the formation of professional reflection of future specialists in physical therapy, ergotherapy.

In our model, the following components of the professional reflection of specialists in physical therapy and ergotherapy are distinguished: motivational target, creative process, emotional strong-willed, communicative technological, control evaluative. In the process of modeling training sessions according to our model, we distinguish five stages.

We suggested that the formation of professional reflection of future specialists in physical therapy, ergotherapy can be represented in the form of successive interconnected stages:

- the first stage (cognitive propaedeutic);

- the second stage (system design);

- the third stage (integrative generalizing).

The analysis of our experimental work showed that the students of the experimental group significantly increased the level of formation of each of the components of professional reflection of specialists in physical therapy, ergotherapy, which confirms the effectiveness of introducing the model we developed for the formation of professional reflection of specialists in physical therapy, ergotherapy in the training process future specialists in physical therapy, ergotherapy.

The results of the study allow us to outline the circle of unsolved problems, the development of which is dictated by the needs of the theory and practice of the entire education system. First of all, it is the need to compare the program for the formation of professional reflection of future specialists in physical therapy, ergotherapy based on the reflective activity approach, as well as the model described in this paper.

Having no experience of independent work with patients, a student cannot rise to the level of rethinking existing stereotypes and changing his professional position, applied methods, methods and forms of patient management under the conditions of industrial practice and in situations simulating the professional activities of physical therapists. And, nevertheless, in the course of experimental work, we observed a steady dynamics in the development of each component of professional reflection of future specialists in physical therapy and ergotherapy.

Issues requiring further study also include substantiation of the forms, means and content of the formation of the reflexive culture of specialists in physical therapy, ergotherapy, research into changes in the level of formation of reflection in the context of professional activities. With the solution of these problems, we connect the prospects for the further development of professional reflection of future specialists in physical therapy, ergotherapy.

\section{References}

1. Becker, M, Dudley-Javoroski, S, Shields, RK. (2017). Professionalism Values in Health Science Education: Self- and PeerAssessment of Faculty. Staff, and Students. Journal of Allied Health, 46(3), 178-184.

2. Branch, WT. (2015). Teaching professional and humanistic values: Suggestion for a practical and theoretical model. Patient Educ Couns, 98, 162-167.

3. Bryan, CS, Babelay AM. (2009). Building character: A model for reflective practice. Acad Med, 84, 1283-1288. 
4. Chan, TM, Thoma, B, Lin, M. (2015). Creating, curating, and sharing online faculty development resources: The medical education in cases series experience. Acad Med, 90, 785-789.

5. Cruess, RL, Cruess, SR, Boudreau, JD, Snell, L, Steinert, Y. (2014). Reframing medical education to support the development of a professional identity. Acad Med, 89, 1446-1451.

6. Daaleman, TP, Kinghorn, WA, Newton, WP, Meador, KG. (2011). Rethinking professionalism in medical education through formation. Fam Med, 43, 325-329.

7. Dmitriieva, NS, Kopochynska, YuV. (2018). Scientific substantiation of application of integrative approach in training of specialists in physical therapy. Molodyi vchenyi, 12, 420-424. doi: https://doi.org/10.32839/2304-5809/2018-12-64-96. (in Ukrainian)

8. Dmitriieva, NS, Kopochynska, YuV. (2019). Formation of the Professional Identity of Future Physical Therapy Specialists as a Factor for Increasing their Competitiveness. Zbirnyk naukovykh prats [Khersonskoho derzhavnoho universytetu]. Pedahohichni nauky, 79(3), 105-110. doi: 10.32999/ksu2413-1865/2019-87-19 (in Ukrainian)

9. Dovidnyk kvalifikatsiinykh kharakterystyk profesii pratsivnykiv. Vypusk 78 «Okhorona zdorov'ia», zatverdzhenyi nakazom Ministerstva okhorony zdorov'ia Ukrainy 29.03.2002 r. № 117 (zi zminamy) [Handbook of qualification characteristics of professions of workers. Issue 78 "Health" approved by the order of the Ministry of Health of Ukraine on March 29, 2002 No. 117 (as amended)]. [accessed 2019 Dec 27]; Retrieved: http://zakon.rada.gov.ua/rada/show/va117282-02 (accessed 09.11.2019). (in Ukrainian)

10. Epstein, RM. (2008). Reflection, perception and the acquisition of wisdom. Med Educ, 42, 1048-1050.

11. Frost, HD, Regehr, G. (2013). "I am a doctor": Negotiating the discourses of standardization and diversity in professional identity construction. Acad Med, 88, 1570-1577.

12. Goldie, J. (2012). The formation of professional identity in medical students: Considerations for educators. Med Teach, 34, 641-648.

13. Griggs, V, Holden, R, Rae, J, Lawless, A. (2015). Professional learning in human resource management: problematising the teaching of reflective practice. Studies in Continuing Education, 37(2),202-217.

14. Harman, K., Sim, M., LeBrun, J., Almost, J., Andrews, C., Davies, H., Khalili,H., Sutton, E., Price, S. (2019). Physiotherapy: an active, transformational, and authentic career choice. Physiotherapy Theory and Practice, 1-14. doi: 10.1080/09593985.2019.1639230.

15. Hendelman, W, Byszewski, A. (2014). Formation of medical student professional identity: Categorizing lapses of professionalism, and the learning environment. BMC Med Educ, 14, 139.

16. Herrick-Reynolds, K., Sewanan, LR., Zheng, DJ., Wang, P., Encandela, J., Shahu, A., Reisman, A. (2019). A novel near-peer reflective writing workshop. Clin Teach, 16, 339-344. doi:10.1111/tct.13057

17. Hojat, M, Michalec, B, Veloski, JJ, Tykocinski, ML. (2015). Can empathy, other personality attributes, and level of positive social influence in medical school identify potential leaders in medicine? Acad Med, 90, 505-510.

18. Jarvis-Selinger, S, Pratt, DD, Regehr, G. (2012). Competency is not enough: Integrating identity formation into the medical education discourse. Acad Med, 87,1185-1190.

19. Karpov, AV. Ponomareva, VV. (2000). Psikhologiya refleksivnykh mehanizmov upravleniya [Psychology of reflexive control mechanisms]. Moscow, IP RAN, 283. (in Russian)

20. Kopochynska, YuV, Dmitriieva, NS. (2019). Basic competences of future specialists in physical therapy and ergotherapy in the development of professional skill. Naukovyi chasopys Natsionalnoho pedahohichnoho universytetu imeni M.P. Drahomanova. Seriia № 15. Naukovo-pedahohichni problemy fizychnoi kultury (fizychna kultura i sport): zbirnyk naukovykh prats, 4 (112), 51 57. (in Ukrainian)

21. Kyte, R, Frank, H, Thomas, Y. (2018). Physiotherapy Students' Experiences of Role-Emerging Placements: A Qualitative Study. International Journal of Practice-based Learning in Health and Social Care, 6, 1-13. doi:10.18552/ijpblhsc.v6i2.505.

22. Madill, A, Sullivan, P. (2010). Medical training as adventure-wonder and adventure-ordeal: A dialogical analysis of affect-laden pedagogy. Soc Sci Med, 71, 2195-2203.

23. Monrouxe, LV. (2010). Identity, identification and medical education: Why should we care? Med Educ, 44, 40-49.

24. Nothnagle, M, Reis, S, Goldman, RE, Anandarajah, G. (2014). Fostering professional formation in residency: Development and evaluation of the "forum" seminar series. Teach Learn Med, 26, 230-238.

25. Rabow, MW, Newman, M, Remen, RN. (2014). Teaching in relationship: The impact on faculty of teaching "the Healer's Art". Teach Learn Med, 26, 121-128.

26. Smith, M, Trede, F. (2013). Reflective practice in the transition phase from university student to novice graduate: implications for teaching reflective practice. Higher Education Research \& Development, 32(4), 632-645.

27. Standart vyshchoi osvity za spetsialnistiu 227 «Fizychna terapiia, erhoterapiia» dlia pershoho (bakalavrskoho) rivnia osvity, zatverdzhenyi nakazom Ministerstva osvity i nauky Ukrainy vid 19.12.2018 r. [Higher education standard in the specialty 227 "Physical therapy, ergotherapy" for the first (bachelor) level of education, approved by the order of the Ministry of Education and Science of Ukraine from 19.12.2018]. [accessed 2019 Dec 27]; Retrieved: https://osvita.ua/doc/files/news/630/63031/227fizichna-terapiya-ergoterapiya-bakal.pdf. (in Ukrainian)

28. Takashima, R, Saeki, K. (2019). Practical Actions Shaped by the Internal Structures of Occupational Therapists' Professional Identities. The Open Journal of Occupational Therapy, 7, 1-16. doi:10.15453/2168-6408.1567.

29. Wald, H. (2015). Professional Identity (Trans)Formation: Reflection, Relationship, Resilience. Acad Med, 90(6), 701-706.

30. Wald, HS. (2011). Insights into professional identity formation in medicine: Memoirs and poetry. Eur Leg Towar New Paradig,16, 377-384. 
31. Weurlander, M, Lonn, A, Seeberger, A, Hult, H, Thornberg, R, Wernerson, A. (2019). Emotional challenges of medical students generate feelings of uncertainty. Med Educ, 53 (10), 1037-1048. doi: 10.1111/medu.13934.

32. Wong, A, Trollope-Kumar, K. (2014). Reflections: An inquiry into medical students' professional identity formation. Med Educ, 48, 489-501.

33. Yardley, S, Westerman, M, Bartlett, M, Walton, JM, Smith, J, Peile, E. (2018). The do's, don't and don't knows of supporting transition to more independent practice. Perspect Med Pract, 7(1), 8-22.

34. Ziebart, C, MacDermid, JC. (2019). Reflective Practice in Physical Therapy: A Scoping Review. Physical Therapy, 99(8),10561068.

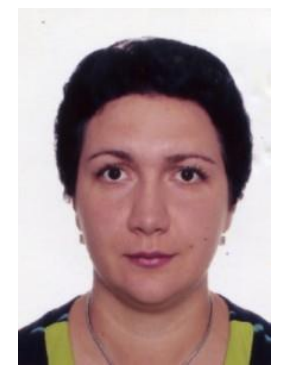

Копочинська Юлія Володимирівна,

к.фіз.вих., доцент кафедри фрізичної терапії

Міжнародний науково-технічний університет імені академіка Ю.Бугая

М.Київ, пров. Магнітогорський 3

Тел. +380970928497 .E-mail: yoiliaco@ukr.net

\section{Kopochynska Yuliia Volodymyrivna,}

Candidate of Science in Physical Education and Sport, Associate Professor

Academician Yuriy Bugay International Scientific and Technical University

Ukraine, Kiev, Lane Magnitogorsk 3 (metro Chernigovskaya)

Тел. +380970928497 . E-mail: yoiliaco@ukr.net

ORCID: 0000-0001-5018-3747

\section{Citation (APA):}

Kopochynska, Yu. (2020). Formation of professional reflection of future specialists in physical therapy, ergotherapy. Engineering and Educational Technologies, 8 (1), 48-58. doi: https://doi.org/10.30929/2307-9770.2020.08.01.04

\section{Цитування (ДСТУ 8302:2015):}

Копочинська Ю. В. Формування професійної рефрлексії майбутніх фахівців з фізичної терапії, ерготерапії / Інженерні та освітні технологіiі. 2020. T. 8. № 1. С. 48-58. doi: https://doi.org/10.30929/2307-9770.2020.08.01.04

Обсяг статmі: сторінок - 11 ; умовних друк. аркушів - 1,593. 